Institutional balancing and international relations theory: Economic interdependence and balance of power strategies in Southeast Asia

He, Kai

Published in:

European Journal of International Relations

DOI:

$10.1177 / 1354066108092310$

Publication date:

2008

Document version

Early version, also known as pre-print

Citation for published version (APA):

$\mathrm{He}, \mathrm{K}$. (2008). Institutional balancing and international relations theory: Economic interdependence and balance of power strategies in Southeast Asia. European Journal of International Relations, 14(3), 489-518. https://doi.org/10.1177/1354066108092310 


\title{
Institutional Balancing and International Relations Theory: Economic Interdependence and Balance of Power Strategies in Southeast Asia
}

\author{
KAI HE \\ Georgia State University, USA
}

\begin{abstract}
This study integrates elements of neorealist and neoliberal theories with a model of institutional balancing that identifies the conditions under which this form of soft balancing occurs. Institutional balancing, i.e. countering pressures or threats through initiating, utilizing, and dominating multilateral institutions, is a new realist strategy for states to pursue security under anarchy. The interplay between the distribution of capabilities and strong economic interdependence shapes states' decisions on when and how to employ this strategy. Historical examples include: inclusive and exclusive efforts by Third World states and the superpowers to organize voting blocs in the UN during the Cold War; inclusive institutional balancing of ASEAN states to constrain China and ensure US support in the ASEAN Regional Forum (ARF) after the Cold War; exclusive institutional balancing of ASEAN states against the US in the ASEAN Plus Three (APT) summit after the Southeast Asian financial crisis. These examples illustrate the logic of institutional balancing under the conditions of bipolarity, incipient multipolarity, and unipolarity.
\end{abstract}

Key Words - ASEAN Plus Three ASEAN Regional Forum - Asian security balance of power - China-ASEAN relations - East Asia Summit - economic interdependence - institutional balancing institutional realism - IR theory

\section{Introduction}

Soon after the Cold War many realists predicted that Asia would be 'ripe for rivalry' or 'back to the future' as a result of the end of bipolarity between the 
US and the Soviet Union (Friedberg, 1993/94; Buzan and Segal, 1994). However, traditional realists seem to be 'getting Asia wrong' given the relative peace in Asia for more than a decade after the Cold War (Kang, 2003). Roughly dividing East Asia into two parts, Northeast Asia and Southeast Asia, the latter is more 'exceptionally' peaceful than the former. While the Korean Peninsula nuclear crisis and tension across the Taiwan Straits are two potential flashpoints endangering the stability of Northeast Asia, there is no serious and imperative, state-based, security threat in Southeast Asia. ${ }^{l}$ Even the territorial disputes over the South China Sea can hardly drive relevant Southeast Asian states into large-scale military conflicts among themselves or with China.

More interestingly, this 'Southeast Asian Exceptionalism' after the Cold War is characterized by the proliferation and dynamics of multilateral institutions in the region driven by the Association of Southeast Asian Nations (ASEAN), especially the inception of the ASEAN Regional Forum (ARF), the institutionalization of ASEAN-Plus Three - China, Japan and Republic of Korea (APT), and the newly emerging, East Asia Summit (EAS). Rather than seeking alliances with great powers, the Southeast Asian states seem confident in relying on multilateral institutions to manage their security after the cold war. ${ }^{2}$

Why did the ASEAN states initiate and promote these multilateral institutions after the Cold War? Realists, especially neorealists, argue that institutions are epiphenomenal in international politics and that assigning importance to ASEAN is a 'categorical mistake' in that the real role of ASEAN in regional security is marginal (Mearsheimer, 1995; Leifer, 1999). However, neoliberals contend that ASEAN is a functional tool for the Southeast Asian states to foster regional cooperation through reducing transaction costs, increasing transparency, and providing focal points (Keohane and Martin, 1995; Simon, 1995). Constructivists suggest that the unique identity and norms of ASEAN states constitute a nascent security community in Southeast Asia through multilateral institutions, in which states basically rule out the use of force to settle regional conflicts (Adler and Barnett, 1998; Acharya, 2000).

In this article, I contend that the above three arguments at best partially explain the dynamics of multilateral institutions in Southeast Asia. First, neorealists are right to highlight the significant role of external powers, such as the US, China, and Japan, in Southeast Asian security, but they fail to account for the institutionalization of regional security after the Cold War. If institutions do not really matter, why do states devote resources and energy to them? In addition, if institutions are only an instrumental tool for stronger states to extend interests and influences as classical realists suggest, why could ASEAN - a group of middle and small powers - take the lead in 
building the regional multilateral institutions after the Cold War? As Joseph Grieco (2002) recognizes, institutionalization in world politics is the weakest link for structural realists.

Neoliberals emphasize the cooperative feature of ASEAN in facilitating regional economic and diplomatic cooperation, such as the establishment of an ASEAN Free Trade Arena (AFTA) and the political coordination of ASEAN states in the Cambodian crisis. However, neoliberalism cannot explain the timing and variations of international institutions in Southeast Asia, i.e. why did multilateral institutions flourish in Southeast Asia only after the Cold War? Why did these institutions malfunction during the 1997 economic crisis? Under what conditions institutions can help states overcome the concern of relative gains in the anarchic system remains an unanswered question for neoliberals.

Social constructivism brings ideational variables, such as norms, identity, and culture, into the study of Southeast Asian security and sheds light on understanding ASEAN's organizational evolution and diplomatic practices, especially the origin and development of 'the ASEAN Way' (Acharya, 2000; Haacke, 2003). However, it seems inadequate by itself to explain patterns of behavior in a broad context, such as the ARF and APT, in which the interactions between ASEAN states and external powers are far beyond the boundaries of shared local identities and norms. In addition, the measurement and operationalization of ideational variables are still highly debated and criticized by rationalist social scientists (Desch, 1998). ${ }^{3}$

The English School of International Relations theory also holds a distinctive perspective on international institutions. The English School defines international institutions as 'a set of habits and practices shaped towards the realisation of common goals ... including ... the balance of power, international law, the diplomatic mechanism, the managerial system of the great powers, and war' (Bull, 1977: 71). On the one hand, this school shares a similar understanding of institutions with social constructivism, which treats institutions as social practices that work to make 'the world hang together' (Ruggie, 1998), i.e. to maintain the international society in Bull's words. On the other hand, the emphasis on sovereignty, territoriality, and material elements of institutions sets a common ground between the English School and realism (Buzan and Wrever, 2003).

While acknowledging here the unique contribution of the English School to the study of international institutions, the research in this article targets primarily the functionality of international institutions in the neorealist, neoliberal, and constructivist schools of International Relations theory. To offset the shortcomings of any one school of general IR theory, I employ below an integrated model of institutional balancing at the interface between neorealism and neoliberalism to explain states' behavior within 
institutions. Then I illustrate its utility with applications to two case studies of ASEAN states' behavior in multilateral institutions in Southeast Asia after the cold war.

\section{Institutional Balancing for Security - Competing by Other Means}

Given the weaknesses of single theories, many scholars advocate a 'tool box' approach to synthesize certain theories to build up new frameworks in Southeast Asian studies. Sheldon Simon (1995) argues for a 'dual-track' strategy in explaining Southeast Asian security by marrying neorealism and neoliberalism. Following the same school of thought, William Tow (2001) advocates a 'convergent security' approach to 'integrate the realist/bilateralist and institutionalist/multilateralist postures for achieving a workable and enduring Asia-Pacific order'.

The institutional balancing model follows Simon's 'dual track' and Tow's 'convergent security' approaches to construct a model with an integrated theoretical framework to explain Southeast Asian security after the Cold War. ${ }^{4}$ Built on neorealism's balance of power theory in conjunction with insights from neoliberalism's interdependence theory and integrated via Joseph Grieco's 'voice opportunity' hypothesis (Grieco, 1995), the institutional balancing model identifies the mechanism of 'institutional balancing', i.e. to counter pressures or threats through initiating, utilizing, and dominating multilateral institutions, as an overlooked realist strategy for states to pursue security under anarchy. ${ }^{5}$ It specifies that (1) high economic interdependence makes states choose a new realist balancing strategy - institutional balancing other than traditional military alliances to cope with threats or pressures from the system; (2) the distribution of capabilities in the regional system indicates how states conduct institutional balancing, either inclusively or exclusively.

The dependent variable in the institutional balancing model is state behavior in the international system. Following the wisdom of neorealism, the typical state behavior under anarchy is balancing, although bandwagoning and buck-passing also happen occasionally (Waltz, 1979: 126). The traditional definition of balancing mainly refers to power balancing or 'hard balancing' in a military sense. Institutional balancing, however, is a new form of balancing - 'soft balancing' behavior. Many realist scholars use soft balancing to explain non-military balancing behavior against the US under unipolarity after the Cold War (Pape, 2005; Paul, 2004, 2005). As T.V. Paul (2004: 3 ) states:

Soft balancing involves tacit balancing short of formal alliances ... [S]oft balancing is often based on a limited arms buildup, ad hoc cooperative exercises, 
or collaboration in regional or international institutions; these policies may be converted to open, hard-balancing strategies if and when security competition becomes intense and the powerful state becomes threatening.

According to this definition, soft balancing could be executed in many ways, including through multilateral institutions. Since this study focuses on why states choose institutions to seek security, I use 'institutional balancing' instead of 'soft balancing' to define a state's balancing behavior through multilateral institutions.

The two forms of institutional balancing are inclusive and exclusive balancing. While the former refers to binding the target states in the institution, the latter means keeping the target states out. In inclusive institutional balancing, states practice norm/rule-building to constrain other states' behavior or control and manipulate agendas to address issues related to their interests in multilateral institutions. In exclusive balancing, states consolidate their political and economic unity to resist pressures from outsiders.

The two independent variables in this model are the degree of economic interdependence among states and the distribution of power in the international system. Three types of polarity will be considered, i.e. unipolar, bipolar, and multipolar systems. In this research, the distribution of power indicating polarity is measured by the neoclassical realist criterion of the perceptions of decision-makers (Rose, 1998). As William Wohlforth (1994: 97) points out, what really matters in policy-making is not power per se, but decision-makers' assessment of power. In order to use the distribution of capabilities/power to explain state behavior, we must specify the transmission belt through which capabilities are translated into actions. Decisionmakers' assessments of power are perfect mechanisms connecting the system effects of power configuration with individual state behavior. Therefore, the distribution of power or polarity in the international system is measured contextually through the perceptions of states' decision-makers rather than purely quantitatively. Leaders' public statements and official documents are major sources for retrieving the perceptions of states.

Perceptions are based on both reality and expectations. On the one hand, quantitative indicators of military capabilities dictate decision-makers' basic assessments of the power configuration in the system. On the other hand, expectations inform policy. All foreign policies are future-oriented, and all decisions are bets on the future. The power configuration in the post-Cold War era is filled with uncertainty and ambiguity. Although the US is the only superpower in the international system, the question about how long this unipolar structure will last is debatable. How states behave under such uncertainty not only depends on assessments of the current situation but also reflects their expected values for the future. 
Besides the distribution of power in the system, the institutional balancing model emphasizes the effects of economic interdependence, an important systemic factor on state behavior but relatively neglected by neorealism. Recalling the 'neo-neo' debate in the 1990s, Helen Milner (1993) and Charles Lipson (1993) criticized neorealism for overemphasizing the constraints of anarchy on state behavior while neglecting interdependence among states. By bridging the gap between neorealism and neoliberalism, the institutional balancing model treats interdependence as another independent variable to account for state behavior.

Following Robert Keohane and Joseph Nye's definition (1989: 8), interdependence refers to 'situations characterized by reciprocal effects among countries or among actors in different countries'. Keohane and Nye (1989: 9) further emphasize that the reciprocal effects of interdependence always involve both costs and benefits, since interdependence restricts autonomy and benefits from interdependence are not always guaranteed. Therefore, interdependence between states will directly or indirectly constrain state behavior in that states have to maximize the benefits and minimize the costs of interdependence by choosing between military balancing and institutional balancing. Military balancing, by definition using alliance formations and arms races to tackle the threat, is not a sensible strategy for a state to deal with its rival under deepening interdependence because of the less friendly nature and the associated negative effects on interdependence. Institutional balancing through multilateral institutions, therefore, becomes an alternative state balancing strategy under high interdependence. ${ }^{6}$

Although in the interdependence literature, security or military interdependence is also discussed, the focus here is on economic interdependence for two reasons. First, security or military interdependence is closely correlated with the distribution of power in the system. Including military interdependence may cause interactions between the two independent variables. Although power is fungible in an absolute sense, this model assumes that economic interdependence is independent from the military distribution of power. Second, traditional realist work sometimes separates the economic realm from the security one. The institutional balancing model integrates these two research domains by introducing the economic interdependence variable into a realist model.

The degree of economic interdependence in the institutional balancing model is coded as weak or strong. The two major indicators used to measure economic interdependence are international trade flows and foreign direct investment (FDI). It should be noted that rather than crudely quantifying interdependence, this study measures interdependence contextually and operationalizes it dyadically. First, the perceptual approach to the distribution of power is also applied to the measurement of interdependence. 
The stronger the perceived interdependence between states, the more likely it is that decision-makers will choose an institutional balancing strategy due to the high costs associated with military balancing. Second, to capture the dynamics of asymmetric interdependence among states, the operationalization of interdependence in this research is a dyadic measurement.

The main hypothesis of the institutional balancing model is that the interplay between the distribution of power in the system and the economic interdependence among states determines state behavior, either hard power balancing or soft institutional balancing. The core causal mechanism in the model is a rationality criterion in the form of cost-benefit calculations as well as expectations of states in making policy decisions. The stronger the decision-makers' perceptions of interdependence, the more risky and costly for states to pursue military balancing, thus the more likely states will engage in institutional balancing. However, different perceptions of power configurations of the system in Figure 1 determine how states conduct institutional balancing, either inclusively or exclusively or both.

\section{Figure 1}

Polarity, Interdependence, and State Balancing

\section{Economic Interdependence}

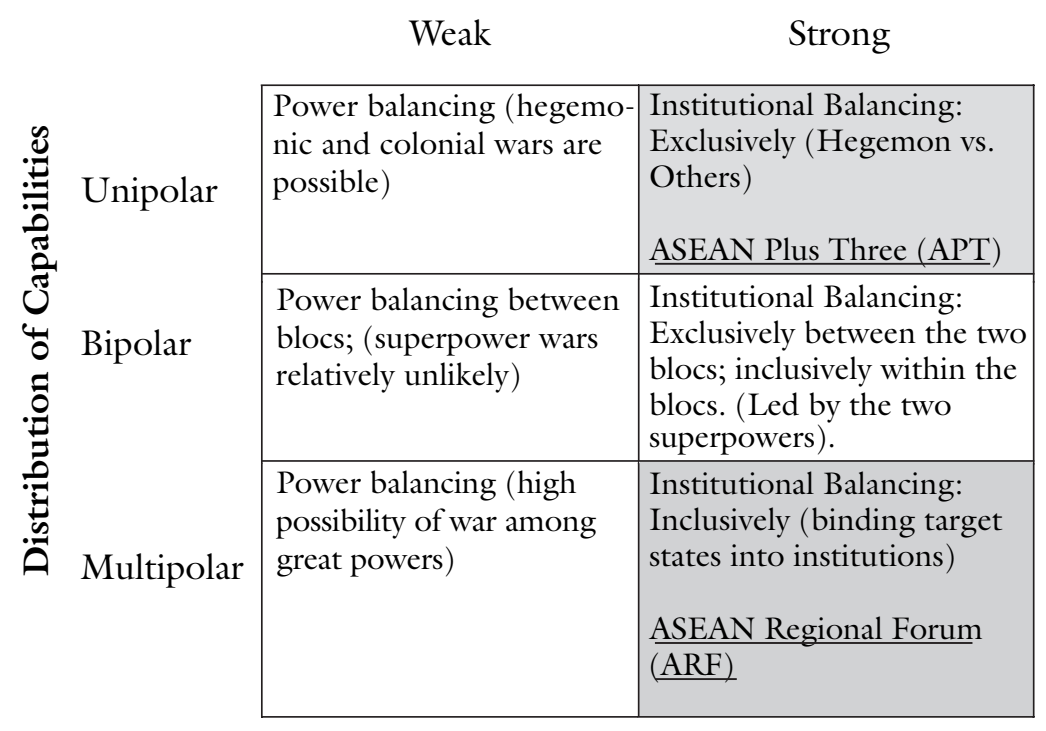

Note: The two shaded cells are examined by the following case studies. 
As shown in Figure 1, when the degree of interdependence is low, power balancing is the major behavior of states. Under unipolarity and low interdependence, the hegemon can initiate wars with relatively low cost if the hegemon chooses to exercise its power in any given region. Under multipolarity, low interdependence increases the possibility of great power wars because of low opportunity costs in terms of economic loss and security damage. Under bipolarity, the two superpowers have high security interdependence but low economic interdependence with each other. However, the power equilibrium between the two superpowers outweighs the negative effect of low economic interdependence on the stability of the system and makes superpower wars relatively unlikely. ${ }^{7}$

If the degree of interdependence is high, institutional balancing is predicted instead of power balancing. In a unipolar world, the power gap between the hegemon and other states limits the options of other states to balance against the hegemon militarily. The hegemon still has more freedom of action in terms of either exercising its power in the region involving its heavy interests or staying out of the region with less strategic values. Other states have two options, either bandwagoning with the hegemon to follow its lead or conducting exclusive institutional balancing to tame the hegemon's primacy. Hoping to constrain the hegemon in any institution will be counterproductive either because the hegemon can afford to break any rules and norms it does not like, or because the hegemon has the capability to control agendas of any institutions in which it is involved.

For example, in the current unipolar world the US as the most powerful state could bypass or ignore the United Nations (UN) resolutions to build a 'coalition of the willing' and wage a war against Iraq. Therefore, under unipolarity the only option for other states to counter the pressure from the hegemon is to conduct exclusive balancing through forming multilateral institutions without the hegemon, in the hope that the unity and cohesion of institutions could help other states say 'no' to the hegemon.

In a bipolar world high interdependence between the two superpowers, especially economic ties, also leads to institutional balancing. Empirically, this is an empty cell between the superpowers because the Cold War was characterized by ideological antagonism and economic isolation between the two blocs. However, theoretically, it is possible that economic interdependence between two superpowers could be high. Following the same logic, the two superpowers would also engage in institutional balancing, through either inclusion or exclusion, toward one another. Actually, both superpowers and smaller powers did practice some institutional balancing within the UN General Assembly via the formation and maintenance of voting blocs during the Cold War. 
In a multipolar world, high interdependence makes institutional balancing more probable due to the high opportunity cost of internal military mobilization and external alliance antagonism. Both inclusive balancing and exclusive balancing are possible options for states although the former may be more popular than the latter. Compared to inclusive balancing, exclusive balancing seems less friendly and may strain the relations between states outside the institution and states inside the institution. In turn, any tension under high economic interdependence will damage the economy and security of involved states and make exclusive balancing counterproductive. Therefore, under multipolarity and high interdependence, inclusive institutional balancing is more sensible for states although exclusive balancing is also possible.

There has been a longstanding debate on the relationship between economic interdependence and international conflict. While commercial liberals believe economic interdependence decreases the possibility of international conflict, neorealists argue that economic interdependence increases the danger of war. In addition, some scholars contend that trade has negligible effects on peace and others argue that the role of economic interdependence depends on other variables, such as democracy, in affecting relations between states. ${ }^{8}$ Standing in-between commercial liberalism and neorealism, I suggest that economic interdependence increases the cost of hard balancing behavior for a state against its rival, but it does not necessarily assure peace between states.

The institutional balancing model does not predict, as neoliberalism does, cooperation among states through institutions. Instead, it predicts institutional struggle, confrontation, bargaining, negotiation, compromise, and balance among states within institutions. The dependent variable in this research is state behavior, military balancing or institutional balancing, rather than political outcomes, war or peace among states. Economic interdependence does not preclude states from choosing military balancing if military balancing can offer them more security. The institutional balancing model specifies that the incentive for states to choose institutional balancing is higher under certain conditions because of rational cost/benefit constraints within the system.

\section{Inclusive Balancing in ARF - Taking China Down and Keeping America In}

The ASEAN Regional Forum (ARF) is the largest multilateral security dialogue forum including all the major powers in the Asia-Pacific. European powers also participate in the ARF as representatives of the European 
Community (EC). ASEAN's policy towards the ARF is an example of an inclusive institutional balancing strategy directed at China and the United States under the systemic constraints in Figure 1 of perceived multipolarity and high economic interdependence. ${ }^{9}$

The end of the Cold War and the termination of antagonism between the two superpowers in 1991 changed the regional power configuration and brought both challenges and opportunities to the ASEAN states. US shaky security commitments and China's rise are two major security concerns confronted by the ASEAN states. After the Cold War the US was the only superpower left in the world, and a unipolar world was taking shape. However, the relative economic decline of the US seriously constrained its security and economic commitments to its Asian allies in the early 1990s. Militarily, the US requested that Japan and South Korea share the costs of maintaining the forward-deployed US troops on their soil. Economically, the US pressed for more open markets throughout the region in order to stimulate its economy. Politically, the United States, the long-term provider of carrots to the ASEAN states, began to show its sticks under the banner of human rights and democracy. The US was widely seen as an 'intruder' upon their political and cultural sovereignty (Stuart and Tow, 1995: 12).

Although ASEAN states appreciated the positive role of the United States in regional security, they were frustrated by the capability and the willingness of the US commitments given America's seeming decline in power and changing strategic interests. Therefore, how to attract US interest while minimizing the negative effect of US political interference in the region became a major strategic challenge for ASEAN after the Cold War. Contrary to the ambiguous US decline, China was clearly rising economically and militarily with an average 8 percent growth rate. It was widely believed that diminishing US influence and commitment in Southeast Asia would create a power vacuum, which would cause new military conflicts and power struggles in the region. Given its economic and military weight, China naturally became the most likely candidate to fill the power vacuum in the eyes of the ASEAN states. In addition, unsettled disputes between China and some ASEAN states in the South China Sea further deepened ASEAN's concerns over the coming 'China threat' (Valencia, 1995).

However, the shifting distribution of power in the international system also brought hopes to ASEAN states. The Asian Century and Asian Miracle arguments prevailed in the region in the early 1990s. Besides China's stunning economic growth, Japan had become the second largest economy in the world since the 1980s. It was widely believed that Japan's economic power was easily fungible to become a military power if and when necessary. In addition, the 'four Asian tigers' (Hong Kong, the Republic of Korea, Singapore, and Taiwan) and the three newly industrializing economies of 
Southeast Asia (Indonesia, Malaysia, and Thailand) were 'making an economic miracle' in the early 1990s (World Bank, 1993: 1).

From Figure 2 we see that the economies of China, East Asia and the Pacific countries grew very fast with a growth rate of over 5 percent while the US had a relatively slow pace (under 5 percent for most of time) in the 1980s. Therefore, it became a widespread belief that if China and the industrializing economies of Southeast Asia could sustain their economic growth after the Cold War, a redistribution of regional power would happen eventually in the Asia-Pacific. If the 20th century belonged to America, the 21st Century would be an Asian one (Rohwer, 1995; Naisbitt, 1995). Wong Kan Seng (1993), then-foreign minister of Singapore, stated in July 1993, 'the simple cold war bipolar model of competition between the United States and the Soviet Union obviously no longer holds. But it is not quite a unipolar world . . . political realities of the post-cold war world are changing the political relationship among equals - a true partnership'.

Although no individual ASEAN state could challenge either China as the rising power or the US as the regional hegemon, there emerged an optimistic view on the future role of ASEAN in regional security. If China's rise and the US decline were inevitable as widely believed in the early 1990s, a multipolar world would replace the unipolar one led by the US. Given ASEAN's diplomatic success in the settlement of the Cambodian crisis and its extraordinary economic performance in the 1980s, it was reasonable for ASEAN states to see an opportunity to play an active role in the future multipolar regional system. As the Foreign Ministers' Joint Communiqué at the end of the 1992 Manila ASEAN Ministerial Meeting stated, 'a profound impact of the end of

\section{Figure 2}

Economic Growth Rates of Major Asian Pacific Economies

GDP Growth Comparison among the US, Japan, China, and East Asian Economies (1979-1997)

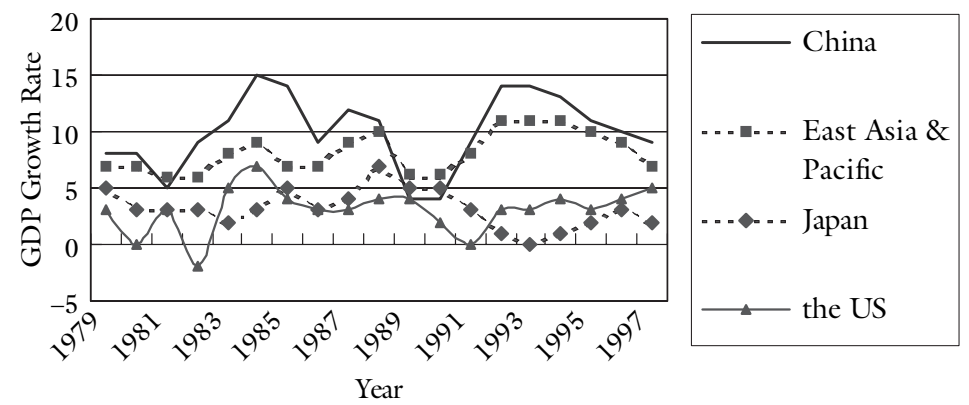

Source: World Development Indicators Database 
the cold war and the East-West confrontation' was the creation of 'new strategic uncertainties' as well as 'fresh opportunities' (ASEAN Secretariat, 1992).

While the ASEAN ministers did not explicitly state what kind of 'fresh opportunities' the end of the Cold War might bring to them, it showed ASEAN's confidence in reshaping regional order in the post-Cold War era. Later Rodolfo Severino (1998), the ASEAN Secretary-General, pointed out clearly, 'the end of the cold war presented ASEAN with the opportunity to help shape the parameters of its own security'. Prachuab Chaiyasan (1997), the then-Minister of Foreign Affairs of Thailand, also stated, 'As the world will increasingly become more multipolar in nature, ASEAN must remain in the driving seat of the ARF process so as to ensure its effectiveness and relevance to our region.' Therefore, in the 1990s, the feeling of uncertainty and cautious optimism about multipolarity largely shaped ASEAN's perception of the regional distribution of power.

According to neorealism, the widely perceived multipolarity with China's rise and US decline as the key variables should lead ASEAN states to forge a military alliance or a de facto alignment with the United States. An alliance with the off-shore and declining balancer would deal with pressures and threats from China as the rising power. Although some ASEAN states maintained their traditional military cooperation with the US, and Indonesia even signed a bilateral security agreement with Australia after the Cold War, ASEAN did not entirely follow the realist prescription. The Philippines and Thailand rejected the US proposal in 1994 for setting up permanent, offshore, pre-positioned, military supplies in their vicinity (Simon, 1996: 21). The major reason for this seemingly contradictory position of ASEAN is rooted in the deepening economic interdependence between ASEAN and China after the Cold War. China's spectacular economic performance since Deng Xiaoping's economic reform has become a major growth engine empowering the regional economy. There are three mainly economic attractions of China for the ASEAN states.

First, China's huge domestic market can stimulate ASEAN's trade-based economic growth. ASEAN's exports to China were $\$ 2.6$ billion in 1990 and jumped to $\$ 39$ billion in 2004 (excluding Hong Kong's \$30 billion in 2004). The so-called ASEAN-5 — Indonesia, Malaysia, the Philippines, Singapore, and Thailand - accounted for 95 percent of these exports (ASEAN Secretariat, 2005). In 2004, China became the fourth largest export market for ASEAN, next to the US, the EU, and Japan. Combining Hong Kong's imports from ASEAN, China and Hong Kong accounted for 13.3 percent of ASEAN's total exports, behind only the US share of 14.2 percent of ASEAN's exports in 2004. In the meantime, ASEAN's imports from China also increased steadily from 4.1 billion in 1991 to 43 billion 
in 2004. China has become the fourth largest import partner of ASEAN since 2001 behind Japan, the US, and the EU (ASEAN Secretariat, 2005: 78-9).

Second, China's rapid economic growth raised ASEAN's expectations of future investments. China's strong economic growth also cultivates hopes in the ASEAN states for future investments. In early 1990, Friedrich Wu (1994), an economist with the Development Bank of Singapore, commented that 'China's emergence as a capital exporter of global reach is far less known than its economic success at home ... [and] . . China [will] capitalize on ASEAN' in the future. According to an official report by the ASEAN-China Expert Group on Economic Cooperation published in 2001: 'In the future, as China's economy gathers strength China's investment abroad will increase ... ASEAN will be a priority market for China's investment in overseas countries in the future, especially if a closer economic relationship between the two sides could be established' (ASEAN Secretariat, 2001). ${ }^{10}$

China's huge market and economic opportunities also attracted ASEAN's interest and thereby softened ASEAN's security policy toward Beijing. One vivid example could be drawn from Mahathir's visit to Beijing in 1993. It was reported that 290 Malaysian businessmen accompanied Mahathir and several joint-venture projects were signed during the visit. On the Kuala Lumpur Stock Exchange, some stocks rose because of the rumors about contracts in China (Vatikiotis, 1993: 13). As Leifer (1996: 18) observed, 'ASEAN strongly resisted any confrontation with China because of its likely impact on the region's economic activity, let alone its security. Indeed, accesses to a burgeoning Chinese market and investment opportunities have persistently constrained such an approach to China.' In other words, the ASEAN states could not rely on traditional military balancing to deal with China's rise because the economic cost and strategic risk would be too high.

Third, a good economic relationship with China can help ASEAN offset political pressures from the West. In the early 1990s, the ASEAN states could not reach consensus on how to deal with these uncertainties caused by the US decline and China's rise. Indonesia planned to refurbish the concept of the Zone of Peace, Freedom, and Neutrality (ZOPFAN) in order to reduce the political influence of external powers. Malaysia proposed upgrading the existing bilateral defense cooperation among Malaysia, Indonesia, and Singapore into a triangular defense framework. Singapore preferred a regional security dialogue with other Asia-Pacific neighbors to address new security concerns in the region (Vatikiotis, 1990, 1991). These different proposals reflected the different strategic interests of ASEAN states in the postcold war era. 
After Suharto visited China in 1990, Indonesia began to lower its unilateral ambition in playing a leading regional role after the Cold War. Michael Leifer (1996: 8) observed, 'Suharto had been astounded by the pace and extent of China's economic development, and was apprehensive about the prospect of that development sustaining a regional assertiveness. Thus Indonesia lent its influential support to private discussions with ASEAN to promote a wider framework for security dialogue beyond the limited bounds of the Association itself.' Given the green light from Suharto, Singapore's multilateral security dialogue framework emerged to become an ASEAN consensus in dealing with the post-Cold War regional security.

The ASEAN states were besieged by offers to join or help build a new security framework in the region during the 1990 ASEAN Post-Ministerial Conference. Both Australia and Canada, ASEAN's dialogue partners, proposed new security dialogue forums like the Conference on Security and Cooperation in Europe (CSCE), which would include ASEAN and other states in the Asia Pacific. The initial responses of ASEAN to these proposals were mostly negative and equivocal. They argued that security issues in Asia were too complex to apply the CSCE model, and they also worried that a CSCE-type arrangement would dilute the association's significance in the longer term.

Nevertheless, the US failed to negotiate a renewal of military bases with the Philippines in September 1991. It meant that the US would physically withdraw from the region in 1992 despite repeated vocal commitments by US officials soon after the military pullout. When the US retreat became a reality, the ASEAN states could no longer keep silent. How to 'keep America in' became one of the major issues at the fourth ASEAN summit in January 1992. Some ASEAN states, such as Singapore and Thailand, signed bilateral military cooperation agreements with the United States to ensure a US presence in the region. In addition, the ASEAN states began to consider the multilateral security dialogue framework to further bind US interests in the region.

At the end of the summit, ASEAN issued a declaration proposed by Singapore, which stated that ASEAN should intensify external dialogue in political and security matters by using the ASEAN Post-Ministerial Conferences. After the Soviet Union's sudden collapse in November 1991, the US under the Bush Administration also began to reassess the utility of multilateral security dialogue in Asia (Baker, 1991). It was reported that Singapore had briefed the US on the multilateral security dialogue plan before the 1992 ASEAN summit (Vatikiotis, 1992: 23). Apparently, the US did not say 'no' to the proposal although it might not have said 'yes' either.

Besides 'keeping America in', the ASEAN states also faced a challenge to 'take China down' through multilateral institutions. In February 1992, 
Beijing passed a national law defining the Spratly Islands as being in its territorial waters, and signed a contract with Crestone Corporation in May to explore oil and gas resources in an area which was disputed with Vietnam. In response to Beijing's assertive claims over the South China Sea, the ASEAN states issued a separate declaration on the South China Sea at its annual foreign ministerial meeting in July 1992, urging the settlement of all sovereign and jurisdictional claims without resorting to force (ASEAN Secretariat, 1996).

Moreover, the ASEAN states collectively called for a US presence in the region at the 1992 Post-Foreign Ministerial Conference. China's assertiveness over the South China Sea helped the ASEAN states reach a consensus on the US role in regional security. As one ASEAN official pointed out, facing China's challenge, 'it is the first time ASEAN as a whole has said that we want the US to stay' (Tasker, 1992: 8-9). It is ASEAN's intention that the US presence would check the assertive behavior of China in the region.

More importantly, the ASEAN states took concrete actions to forge a multilateral security dialogue to engage and constrain China during the 1993 ASEAN Post-Ministerial Conference. ASEAN pushed for setting up a formal ASEAN Regional Forum to discuss political and security issues in the Asia-Pacific. One year after, the first formal ARF meeting was held in Bangkok in July 1994. ARF then became an important institutional tool for the ASEAN states to bind US interests and tackle China's threats after the Cold War.

ARF's broad institutional setting and security agenda attracted US interests. Security issues discussed at the ARF were not limited to Southeast Asia, as the ARF tried to address almost all the flashpoints in world politics. Although the potential crisis between Taiwan and China was never included in the formal agenda of the ARF because of China's strong objection, the ARF did provide an opportunity for the concerned parties, especially the US and China, to address their concerns on a regular basis.

For example, China-US relations soured after the US allowed President Lee Teng-Hui of Taiwan to visit the US in June 1995. The second ARF meeting in August 1995 provided a useful informal opportunity for the Chinese and US foreign ministers to defuse the immediate tension between these two countries. As Leifer (1996: 43) observed, 'the US Secretary of State's interests in the multilateral enterprise increased significantly after that meeting'. Although the US also occasionally displayed frustration about its slow progress and the 'talk shop' nature in addressing regional security issues, to date no alternative multilateral institutions are available for the US to substitute for ARF. After the September 11 tragedy, the US suddenly also discovered the utility of ARF in forming an international frontline in its global war on terror. 
The major achievement of the ARF lies in its inclusive balancing strategy towards China in terms of constraining China's assertiveness over the South China Sea. Contrary to military balancing, ASEAN engaged China with a multilateral security dialogue and used institutional norms and rules to constrain China's behavior. As mentioned before, the ASEAN states issued a joint declaration, calling for a peaceful resolution in response to China's 1992 passage of a national law on territorial waters. However, China did not take ASEAN's 1992 declaration seriously. Qian Qichen, the foreign minister of China, stated only that China 'appreciated some of the basic principles' in the declaration (Tasker, 1992: 9).

In the first ARF meeting in 1994, Qian refused to discuss the sovereignty disputes over the South China Sea within a multilateral format although he reiterated China's peaceful intentions in settling the disputes. However, ASEAN successfully convinced China to endorse the Treaty of Amity and Cooperation (TAC), originally signed by the ASEAN states in 1976, as a regional code of conduct in the first ARF meeting. Since the TAC formally called for 'settlement of differences or disputes by peaceful means' and 'renunciation of the threat or use of force' (ASEAN Secretariat, 1976), China's policy on the South China Sea was also automatically and morally constrained by the Treaty in the ARF setting although the legalistic constraints of TAC on China's behavior were not in effect until China signed the TAC in 2003.

The February 1995 Mischief Reef incident between China and the Philippines, in which China was revealed to have occupied the disputed Mischief Reef, further showed the effectiveness of ASEAN's institutional balancing strategy. After a short silence, ASEAN states consolidated their common policy on the South China Sea. In March 1995, ASEAN issued a strong joint statement to support the Philippines' appeal to prohibit the occupation of additional islands in the Spratlys. During the security dialogue between ASEAN and China in April, ASEAN showed its solidarity again over the South China Sea issue. Reportedly ASEAN's unity was a big surprise to China and led directly to China's concessions at the second ARF meeting in August 1995. China for the first time agreed to conduct multilateral discussions on the South China Sea disputes with ASEAN states. Moreover, China also indicated its willingness to discuss the disputes on the basis of recognized principles of international law, including the 1982 Law of the Sea.

In 1995, China also agreed with ASEAN's suggestion to conduct an annual consultation on political and security issues at the senior official level, the 'Senior Official Conference' (SOC), which became another important multilateral institution between China and ASEAN. While ARF was a major institutional tool for ASEAN to constrain China's assertive behavior in a broader international setting, SOC became a diplomatic arena for ASEAN 
and China to conduct practical negotiations over the South China Sea issue. ${ }^{11}$ In 1999, China accepted ASEAN's proposal to sign a code of conduct over the disputed areas in the South China Sea. In 2002, China and ASEAN finally signed a 'Declaration on the Conduct of Parties in the South China Sea', through which China and ASEAN committed to resolve the disputes over the South China Sea peacefully. ${ }^{12}$ In addition, China signed the TAC in 2003 to further legally commit to its non-aggressive policy in Southeast Asia and further alleviate ASEAN's suspicions over the South China Sea disputes.

Although the series of agreements and cooperation treaties between ASEAN and China do not guarantee a perpetual peace over the South China Sea, the strategic goal of ASEAN states to engage China through a multilateral institution has been fulfilled so far. China has changed its strong attitude on the South China Sea to a benign and cooperative policy since it joined the ARF, though some scholars questioned the real intention behind China's 'smiling face' (Emmers, 2003). ${ }^{13}$ The major merit of ARF is to provide a new means for ASEAN to balance the potential threat from China, while at the same time avoiding military rivalry and antagonism that could destroy regional stability and prosperity. The institutional balancing model does not predict what China will do in the future. The effectiveness of institutional balancing depends on the regional distribution of power, the interdependence between ASEAN and China, as well as the solidarity of ASEAN. ${ }^{14}$

\section{Exclusive Balancing in APT - An Asian Bloc without the US}

Besides ARF, ASEAN also conducts an exclusive institutional balancing strategy through the APT summit (the ASEAN-Plus Three - China, Japan, and South Korea), established in 1997 in order to promote economic cooperation between Southeast Asia and East Asia and to deal with US pressure after the 1997-98 Asian economic crisis. ${ }^{15}$ Differing from inclusive balancing through ARF, ASEAN's APT strategy is exclusive institutional balancing in that the US is deliberately excluded by the APT. The Asian economic crisis demolished ASEAN's multipolar and 'Asian century' dreams after the Cold War. The ASEAN states had to accept that the world was still unipolar and the US was at the top. The APT, therefore, is ASEAN's institutional response to unipolarity and high economic interdependence specified by the institutional balancing model.

The significance of APT is better understood when compared with the previously failed attempts of the East Asian Economic Group (EAEG) and the East Asian Economic Caucus (EAEC) in the early 1990s. In December 1990, Mahathir proposed setting up EAEG as a trade bloc in Asia to counter economic pressure from the North American Free Trade Agreement 
(NAFTA) and the EC. The proposed EAEG consisted of six ASEAN members, three Indochina countries, plus China, Japan, South Korea, Hong Kong and Taiwan (Vatikiotis et al., 1991: 32). However, the EAEG proposal was not carried out because of opposition from Indonesia, Japan, and the US.

Although all ASEAN states worried about the economic pressure from other trading blocs and increasing regionalism, they did not reach a consensus over how to deal with these challenges. Japan in particular displayed reservations about the EAEG out of fear that it would damage its relations with the US, which was deliberately excluded from the plan. In addition, as Simon (1996: 20) suggests, the real target of EAEG might not be the US but Japan, in that 'the EAEG may well be a device to open Tokyo's market to Asian exporters'. Although Mahathir redefined the purpose of the idea and renamed it EAEC (East Asian Economic Caucus), given US objections and Japan's ambivalence, the EAEC was shelved by the ASEAN states after 1993.

The failed EAEG/EAEC proposals revealed two difficulties for states in conducting exclusive institutional balancing in the early 1990s. First, exclusive institutional balancing should have a clear target, and in-group consensus is essential for success. Although Mahathir was at odds with the West, especially the US, ASEAN states such as Indonesia and Singapore did not share Mahathir's extreme anti-US sentiment. Instead, most ASEAN states and Japan tried to tie the US to the region for economic and military gains. Second, the deep economic dependence of ASEAN on the US was another obstacle for ASEAN to initiate external balancing. The US was one of the most important trading partners and was also the major origin of Foreign Direct Investment and technology for ASEAN.

Indonesia clearly stated that Mahathir's trading bloc plan was not fit for the post-Cold War reality. Instead, Indonesia supported the idea of open regionalism, such as APEC, including the US and other Pacific economic powers. Although Mahathir's real reason for advocating the EAEG/EAEC may not have been to antagonize the US but to enhance the bargaining power of the ASEAN states versus the US and the West, other ASEAN states and Japan did not buy Mahathir's plan.

These two obstacles for ASEAN states for conducting exclusive institutional balancing were removed by the 1997 financial and economic crisis in Asia. The economic crisis first hit Thailand in July 1997 and then quickly spread to other ASEAN states and South Korea. The real reason for the 1997 economic crisis is complicated and so far still debatable. However, almost all affected states were disappointed with or resented the arrogant US policies during the crisis. The major aspiration for closer East Asia cooperation under the APT flag resulted from the frustration and 
disappointment in the reluctant role of the US in the economic crisis (Webber, 2001: 358; Beeson, 2003).

The US did not directly offer any substantial help to the affected Southeast Asian countries. Instead, the IMF (led by the US) was the major player in rescuing the economies in Southeast Asia. The IMF's prescriptions for the crisis were to cut government spending, reduce subsidies, and raise interest rates to stabilize local currencies. Many observers criticized the appropriateness of IMF solutions because one major problem for the Asian crisis originated in private debts and not government misbehavior (e.g. Sachs, 1997; Vatikiotis, 1998). Many countries were offended by the IMF requests and thereby implemented them halfheartedly.

To make things worse, the economic crisis also caused political disorder and turmoil. Suharto, Indonesia's president for three decades, stepped down in May 1998 after widespread social and ethnic riots in Jakarta. Thailand, the Philippines, and South Korea all experienced political power transitions during the crisis. Many Southeast Asian countries perceived the IMF as a blunt instrument of US policy in promoting economic liberalization and political democratization in Asia. And the resentments towards the IMF after the crisis were to a large degree translated into a widespread anti-US sentiment in Southeast Asia.

In addition, the US strongly opposed the Asian Monetary Fund (AMF) proposal. During the early stage of the crisis, Japan proposed to establish the AMF to support local currencies in order to prevent a regional economic meltdown. However, the IMF and the US opposed Japan's plan and argued that it would create a 'moral hazard' in that the affected countries did not need to implement the IMF requests in order to get the aid they needed. More importantly, the US worried that the AMF would erode the primary role of the IMF in Asia and also damage the US domestic economy if the Japanese yen became the dominant foreign reserve currency in Asia instead of the US dollar.

The economic crisis and the later Kosovo War in 1999 changed the previous perceptions of the ASEAN leaders on the US decline and multipolarity. The ASEAN states began to realize that the US would remain the most powerful state in the world for a long time both militarily and economically, and a multipolar world was still far away. The indifferent and arrogant policy of the US towards the ASEAN states during the crisis also made the ASEAN states aware of the danger of a unipolar world. They began to think about how to strengthen their economic security and reduce economic dependency towards the outside powers, especially the US, after the crisis.

The economic crisis also changed ASEAN's perception of economic interdependence with the US. Before the crisis, the ASEAN states believed that because the US has a huge stake in the region's economy, it would not 
ignore the region during the crisis. However, the crisis proved the ASEAN states wrong. First, the US economy was not really affected by the crisis, which could partially explain the indifferent attitude of the US during that troubled time. Second, the crisis revealed the vulnerability of Asian economies caused by their over-dependence on the US, and US-led, international financial institutions.

The crisis did not change the fact that the US is the most important trading partner of the ASEAN states. It actually deepened the trade dependency of ASEAN on the US, because the US market is the key for the economic recovery of the ASEAN states. However, the economic crisis did teach the ASEAN states how important 'money' other than 'trade' is to their economies. Because of the globalization of financial markets, how to manage the rapid, cross-border, capital flows has become the new challenge for ASEAN states. The existing, US-led, world financial system under the IMF and the World Bank is problematic and inadequate at best. As Bergsten (2000) points out, the East Asian states do not reject existing multilateral institutions, such as the IMF and the World Bank, but they want to establish their own institutions in order to supplement existing structures and to ensure that they will never again be so dependent on outsiders.

ASEAN states were not the only victims in the crisis. South Korea, Japan, and even China were affected by the crisis in different degrees. Therefore, these three countries also shared ASEAN's resentment towards the US and the urgency for regional financial cooperation after the crisis. In December 1997, ASEAN sponsored the first informal East Asia Summit, inviting China, South Korea, and Japan, which later became widely known as ASEAN-Plus Three (APT) cooperation. The first APT did not achieve anything substantial besides leaders' rhetorical pledges for regional cooperation. At the 1998 APT in Hanoi, the APT was further institutionalized by the ASEAN states. The APT leaders agreed to hold the summit regularly. In addition, the APT would include a series of ministerial-level meetings for finance and foreign ministers.

The first substantial concrete achievement of APT was the Chiang Mai Initiative reached at the $2000 \mathrm{APT}$ summit in Thailand. The so-called Chiang Mai Initiative is to establish a regional currency swap facility between the central banks to enable the states to protect themselves better against future currency speculators' attacks. In addition, it called for cooperation in the areas of capital flow monitoring, self-help and support mechanisms, and international financial reforms. Some observers praise the Chiang Mai Initiative as representing the beginning of a new era of regionalism. Richard Stubbs (2002: 441) even suggests that the APT has the potential to become the dominant regional institution in East Asia. 
For the ASEAN states, APT cooperation aims at helping balance the economic domination of the US and Western financial institutions, like the IMF and the World Bank. To a certain extent, APT is a delayed realization of Mahathir's EAEG/EAEC proposals. However, APT differs from EAEG/EAEC in two ways. First, EAEG/EAEC aimed at establishing a trading bloc including all the economies in Asia such as Hong Kong and Taiwan. However, APT focused on financial and economic cooperation between sovereign governments. Second, while EAEG/EAEC narrowly emphasized trade liberalization within its original proposal, APT has gradually expanded to political and security issues from initial financial cooperation.

Unlike the inclusive institutional balancing strategy practiced in the ARF, i.e. to drag all major powers in, the ASEAN states hoped that an exclusive institutional balancing strategy could form an East Asian entity and keep the US out in order to balance against the pressures from the West, especially from the US. However, the APT is by no means a tool of ASEAN to antagonize the US. Rather, the ASEAN states intend to use the APT to emphasize their relevance in the region and hopefully to increase their bargaining power with the US and the West.

It is worth noting that China plays an indispensable role in strengthening APT cooperation. For China, APT is not only an exclusive institutional balancing strategy to undermine US influence in the region, but also an inclusive institutional balancing policy to further engage ASEAN. At the 2004 APT meeting, China initiated a new 'East Asia Summit' (EAS) framework as a forum for regional economic and security issues. China gained political support from some ASEAN states, especially Malaysia, which was fascinated by the idea of establishing a non-Western Asian bloc in the early 1990s. Although Indonesia and Singapore were concerned that China's strategic intention might irritate the US, neither of them would publicly take the lead to be at odds with China or Malaysia. The Chairman's Statement at the 2004 APT meeting agreed that the first East Asian Summit would convene in Malaysia in 2005.

However, China and Malaysia's original EAS proposal was challenged by Indonesia and Singapore with support from Japan. China and Malaysia wanted to upgrade the APT framework to enhance political and security cooperation among Asian countries without admitting new members. Japan, Indonesia, and Singapore insisted that the EAS should expand and absorb new members, such as Australia, New Zealand, and India in order to increase the 'effectiveness' of regional cooperation. Although no one publicly mentioned it, Japan, Indonesia, and Singapore's proposal for more members was to prevent China from dominating the regional community.

In December 2005, the first EAS meeting was held in Malaysia. The heads of states from the original 13 APT members and India, Australia, and 
New Zealand conducted a three-hour dialogue not only on economic cooperation but also on political and security issues. Later, they agreed to convene the summit regularly. Although the future of EAS is still unclear because of the institutional struggle and confrontation between China, Japan, and some ASEAN states, ASEAN's strategic purpose through EAS is clear, i.e. exclusive institutional balancing against the US. Since the United States is not a part of EAS, the cohesion and success of the EAS cooperation will help ASEAN deal with US economic pressure and political influence in the region.

The major reason for excluding the US is because the US was reluctant to sign ASEAN's Treaty of Amity and Cooperation (TAC), the prerequisite for EAS participation. Since the TAC is a non-aggression pact, which requires all signatories to resolve disputes peacefully, some US officials worry that it would constrain US military activities in the Pacific (Simon, 2005). It is still not clear whether the US will sign the TAC to participate in the future EAS meeting as Australia and New Zealand did in 2005. Nevertheless, the US signature on the TAC would definitely be a sign of the great success of ASEAN's institutional balancing through the EAS.

The inception of EAS could be seen as an expanding balancing strategy of APT towards the US, initiated by the ASEAN and supported by other participants. However, it could also be seen as an indication of the weakness of APT in balancing the US. As Hadi Soesastro (2006: 51) points out, 'concerns about ASEAN-Plus Three's waning momentum spurred Malaysia to assert regional leadership by resurrecting the EAS'. In other words, the EAS is another attempt of ASEAN to deliver their balancing message towards the US after the failure of previous APT practices. The effectiveness of ASEAN's institutional balancing through either APT or EAS depends on how the US changes its policy towards the ASEAN states.

\section{Conclusion}

The current debate on soft balancing in international relations focuses on whether soft balancing is a distinctive foreign policy behavior under unipolarity. While proponents of soft balancing theory argue that US unilateralism has provoked other states to soft balance against US primacy, critics argue that these so-called soft balancing behaviors are only 'unipolar politics as usual', or 'diplomatic frictions' that accompany history (Brooks and Wohlforth, 2005; Lieber and Alexander, 2005). Moving beyond debating on whether it is legitimate to coin 'soft balancing' in international relations, I have examined under what conditions and how the ASEAN states have used two distinctive, soft-balancing strategies, inclusive institutional balancing and exclusive institutional balancing, to pursue security under anarchy. Not only 
does this study strengthen the theoretical framework of soft-balancing arguments, it also responds to the criticisms of soft balancing in a vigorous, empirical way.

Integrating neorealist and neoliberal theories, this analysis suggests that institutional balancing, i.e. countering pressures or threats through initiating, utilizing, and dominating multilateral institutions, is a new realist strategy for states under high economic interdependence. High economic interdependence is a necessary condition under which states may prefer institutional balancing to military balancing, and the distribution of capabilities in the system shapes how states employ this new strategy, i.e. inclusively or exclusively. Although institutional balancing practices between the two superpowers were overshadowed by the ideological antagonism and military competition during the Cold War, nonetheless the high economic interdependence within the two camps made the two superpowers and some smaller countries organize inclusive and exclusive voting blocs in the UN.

Three strategic uncertainties - US commitment, China's rise, and the unclear regional distribution of power - led the ASEAN states to redefine their security challenges in the post-Cold War era. The increasing economic interdependence in the region along with international trade and foreign investment rendered traditional military balancing inadequate in dealing with ASEAN's security concerns. ASEAN states, therefore, chose institutional balancing to pursue security, i.e. relying on multilateral institutions to bind and constrain targeted challengers or using institutions to countervail the pressures from potential threats.

The widely perceived multipolarity in the early 1990s guided the ASEAN states to employ an inclusive institutional balancing strategy toward China through the ARF. For dealing with China's increasing assertiveness in the South China Sea, the ASEAN states initiated and established the ARF in 1994. The APT and later EAS are rooted in the regional resentment towards the US and urgency of regional financial cooperation during the 1997 economic crisis against the background of the US-led, unipolar world. The US and Western multilateral institutions, such as the IMF and the World Bank, are the major balancing targets in the APT and EAS frameworks. As Stuart Harris (2000: 502) suggests, 'regional multilateralism [in Asia, such as ASEAN, ARF, APEC and ASEM] has helped smaller countries to balance, with norms and peer pressure, the regional dominance of Indonesia and Japan, to integrate China into the region and to limit US unilateralism'.

The future challenge for ASEAN is how to strengthen its internal solidarity and keep external relevance through these multilateral institutions. The major reason for the successful institutional balancing is that ASEAN can take the driving role, which facilitates ASEAN's ability to control the agenda and set up norms according to their interests in multilateral institutions. So 
far, ASEAN still maintains its pivotal role in ARF, APT and EAS. Whether ASEAN can remain in the driving seat in these multilateral institutions despite challenges from other member states is an important question for the future success of ASEAN's balancing strategy. Although the ASEAN states could enhance its regional relevance by strengthening their internal coherence, the level of economic interdependence and the regional distribution of power shape and direct the success of ASEAN's institutional balancing.

\section{Notes}

The author owes special thanks to Sheldon Simon, Stephen Wolker, Huiyun Teng, and the anonymous reviewers for their constructive comments and suggestions.

1. After the September 11 terrorist attacks in 2001, terrorism became one of the security threats to international peace, including in Southeast Asia. However, in Southeast Asia terrorism has not been a major security threat to regional stability, although some Southeast Asian states face religious extremist and separatist problems, such as southern Thai and southern Philippine insurgencies. For terrorism and its influence on international politics, see Jervis (2002).

2. It is worth noting, however, that the United States maintained and even strengthened its traditional bilateral military cooperation with some Southeast Asian states, such as Singapore, Thailand, and the Philippines after the Cold War. But military cooperation between the United States and its Southeast Asian partners is by no means as well developed as the strengthened military alliance between the US and Japan and the successful expansion of NATO in Europe during the post-Cold War era. The power asymmetries between Southeast Asian countries and the US preclude the effectiveness of bilateral balancing on regional security. Therefore, it is difficult to fully explain the 'exceptional peace' in Southeast Asia after the Cold War through the prism of United States-led bilateralism. This study focuses on the institutionalized multilateral security dynamics in Southeast Asia while acknowledging the continuing importance of bilateralism.

3. Some recent constructivist works do take methodology seriously. See the special issue on institutions and socialization in International Organization, edited by Jeffrey Checkel (2005).

4. For an even more eclectic approach, see Alaggapa (2003) and Katzenstein and Okawara (2001).

5. Joseph Grieco suggests a 'voice opportunity' hypothesis in examining the regional monetary integration of European Union in the 1990s. He argues that weak but influential states (such as France and Italy) treat institutions as a means to constrain strong states (Germany) and to increase their weight in regional decision-making. However, he does not specify under what conditions weak states would use their 'voice' to bind strong states. The institutional realist model in this article modifies the key assumption of the 'voice opportunity' hypothesis by introducing another systemic variable - interdependence - to specify when and why weak states can successfully use institutions as a means of pursuing their 
security. In addition, the institutional balancing model expands the application of the 'voice opportunity' hypothesis from economic cooperation to security issues.

6. Keohane and Nye's argument, that the role of international organizations will increase under the ideal situation of 'complex interdependence' follows the same line of reasoning as institutional balancing. See Keohane and Nye (1989: 35-7).

7. It is worth noting that Waltz argues that both military and economic interdependence in a bipolar world are lower than in a multipolar one. Therefore, Waltz concludes that bipolarity is more stable than multipolarity, because low interdependence reduces the chance of conflict among states (Waltz, 1979: 138, 169).

8. For a general review of different perspectives on economic interdependence and conflict, see Chapter 1 in Mansfield and Pollins (2003). For the argument that trade competition and the expansion of imperialism led to the First World War, see Alexander (2005) and Lenin (1948). Realists who argue that economic interdependence or trade in particular cannot prevent conflicts and may even have stimulated the outbreak of war include Waltz (1979) and Gilpin (1981). The contrary argument regarding trade and interdependence as likely to mitigate or prevent war is in Rosecrance (1986) and in Chapter 2 of Keohane and Nye (1989).

9. There are ten members in ASEAN now and strictly speaking, there is no common ASEAN foreign policy per se. However, most of the ASEAN states' international prestige is built on their diplomatic cooperation and foreign policy coordination on the international stage, such as in mediating in the Cambodian crisis in the late 1980s. Therefore, this research focuses on the convergent points of cooperation in the ASEAN states' foreign policies on multilateral institutions after the Cold War while addressing their different strategic concerns when necessary.

10. Bilateral investments between China and ASEAN were unbalanced in the early 1990s in that ASEAN's investments in China significantly outweighed China's in ASEAN. After the 1997 economic crisis, China began to increase its investments and form free trade agreements to offset the unbalanced mutual FDI with ASEAN. However, given China's economic potential, the expected utility of China's investment still attracted ASEAN's strategic attention.

11. After the 1995 ARF meeting, the negotiation over the South China Sea disputes between China and ASEAN took place at the 'Senior Official Conference' because of China's concern over US interference. The constraining role of ARF on China's behavior focused on increasing military transparency and enhancing confidence building measures (CBMs) after 1995. For the role of ARF in regional security, see Heller (2005).

12. The Declaration of Conduct was a compromise between China and the ASEAN states. China insisted that the declaration of conduct only applied to the Spratly Islands, and the Paracel disputes between China and Vietnam were excluded. The final declaration dropped any specific references to the disputes, using instead a general term - the South China Sea - to cover the disagreement between China and Vietnam. Vietnam may interpret the Declaration as applying to the Paracels, while China may assert that it does not. In addition, the original document's title was changed from the forceful 'code of conduct' to the 'declaration of conduct', which has no legal obligation as originally proposed by ASEAN. These changes in 
wording led some scholars to downplay the significance of the Declaration over the South China Sea disputes (Tonnesson, 2002: 145-69; Emmers, 2002).

13. China's 'smiling face' policy toward Southeast Asia after the Cold War deserves in-depth investigation, which is beyond the scope of this article. Other rival arguments, such as the deterioration in Sino-US and Sino-Japan relations, may also explain China's changing policies toward ASEAN. This article only suggests one possible explanation from an institutional balancing perspective while acknowledging the existence of rival theories.

14. Regarding China's changing behavior in ARF, Johnston suggests a socialization argument which focuses on exploring how some norms, such as cooperative security, were internalized among state agents, Chinese diplomats and policymakers, through the ARF practices. See Johnston (2003).

15. The 10 (ASEAN) plus 3 (China, Japan, and South Korea) grouping of the APT framework first appeared at the first Asia-European Meeting (ASEM) in 1996, in which the Asian countries formed an ad hoc gathering in order to facilitate a discussion with their European counterparts. To a certain extent, ASEM could be seen as an exclusive institutional balancing strategy of Asia and Europe in dealing with US pressure. However, ASEM encountered some obstacles because of the divergent views of the EU and ASEAN toward Myanmar's domestic situation. This article focuses on APT while acknowledging ASEM's importance.

\section{References}

Acharya, Amitav (2000) Constructing a Security Community in Southeast Asia: ASEAN and the Problem of Regional Order. London: Routledge.

Adler, Emanuel and Michael Barnett (eds) (1998) Security Communities. Cambridge: Cambridge University Press.

Alaggapa, Muthiah (ed.) (2003) Asian Security Order: Instrumental and Normative Features. Stanford, CA: Stanford University Press.

Alexander, Bevin (2005) How America Got it Right: The US March to Military and Political Supremacy. New York: Crown.

ASEAN Secretariat (1976) 'Treaty of Amity and Cooperation in Southeast Asia', Indonesia, 24 February. See http://www.aseansec.org/1217.htm.

ASEAN Secretariat (1992) 'Joint Communiqué 25th ASEAN Ministerial Meeting Manila', Philippines, 21-22 July. See http://www.aseansec.org/1167.htm.

ASEAN Secretariat (1996) 'ASEAN Declaration on the South China Sea', see www.aseansec.org/1996.htm.

ASEAN Secretariat (2001) 'Forging Closer ASEAN-China Economic Relations in the Twenty-First Century', see http://www.aseansec.org/asean_chi.pdf.

ASEAN Secretariat (2005) ASEAN Statistical Yearbook 2005. see http://www. aseansec.org/18175.htm.

Baker, James (1991) 'America in Asia', Foreign Affairs 70(5): 1-18.

Beeson, Mark (2003) 'Asean Plus Three and the Rise of Reactionary Regionalism', Contemporary Southeast Asia 25(2): 251-68. 
Bergsten, Fred (2000) 'East Asian Regionalism: Towards a Tripartite World', The Economist 15 July: 23-6.

Brooks, Stephen and William Wohlforth (2005) 'Hard Times for Soft Balancing', International Security 30(1): 72-108.

Bull, Hedley (1977) The Anarchical Society, 2nd edn. New York: Columbia University Press.

Buzan, Barry and Gerald Segal (1994) 'Rethinking East Asian Security', Survival 36(2): 3-21.

Buzan, Barry and Ole Wrver (2003) Regions and Powers: The Structure of International Security. Cambridge: Cambridge University Press.

Chaiyasan, Prachuab (1997) 'Opening Statement of His Excellency Mr Prachuab Chaiyasan Minister of Foreign Affairs of Thailand', Kuala Lumpur. See www.aseansec.org/4353.htm.

Checkel, Jeffrey (2005) 'International Institutions and Socialization in Europe: Introduction and Framework', International Organization 59(3), Special Issue on institutions and socialization.

Desch, Michael (1998) 'Culture Clash: Assessing the Importance of Ideas in Security Studies', International Security 23(1): 141-70.

Emmers, Ralf (2002) 'ASEAN, China, and the South China Sea: An Opportunity Missed', IDSS Commentaries (November).

Emmers, Ralf (2003) Cooperative Security and the Balance of Power in ASEAN and $A R F$. London: RoutledgeCurzon.

Friedberg, Aaron (1993/94) 'Ripe for Rivalry: Prospects for Peace in a Multipolar Asia', International Security 18(3): 5-33.

Gilpin, Robert (1981) War and Change in World Politics. New York: Cambridge University Press.

Grieco, Joseph (1995) 'The Maastricht Treaty, Economic and Monetary Union and the Neo-realist Research Programme', Review of International Studies 21(1): 21-4l.

Grieco, Joseph (2002) 'Modern Realist Theory and the Study of International Politics in the Twenty-First Century', in Michael Brecher and Frank P. Harvey (eds) Millennial Reflections on International Studies, pp. 65-78. Ann Arbor, MI: The University of Michigan Press.

Haacke, Jürgen (2003) ASEAN's Diplomatic and Security Culture: Origins, Development and Prospects. London: RoutledgeCurzon.

Harris, Stuart (2000) 'Asian Multilateral Institutions and their Response to the Asian Economic Crisis: The Regional and Global Implications', The Pacific Review 13(3): 495-516.

Heller, Dominik (2005) 'The Relevance of the ASEAN Regional Forum (ARF) for Regional Security in the Asia-Pacific', Contemporary Southeast Asia 27(1): 123-45. Jervis, Robert (2002) 'Theories of War in an Era of Leading-Power Peace', American Political Science Review 96(1): 1-14.

Johnston, Alastair (2003) 'Socialization in International Relations: The ASEAN Way and International Relations Theory', in G. John Ikenberry and Michael 
Mastanduno (eds) International Relations Theory and the Asia-Pacific, pp. 107-62. New York: Columbia University Press.

Kang, David (2003) 'Getting Asia Wrong: The Need for New Analytical Frameworks', International Security 27(4): 57-85.

Katzenstein, Peter and Nobuo Okawara (2001) 'Japan, Asian-Pacific Security, and the Case for Analytical Eclecticism', International Security 26(3): 153-85.

Keohane, Robert and Lisa Martin (1995) 'The Promise of Institutionalist Theory', International Security 20(1): 39-51.

Keohane, Robert and Joseph Nye (1989) Power and Interdependence, 2nd edn. New York: HarperCollins.

Leifer, Michael (1996) 'The ASEAN Regional Forum', Adelphi Paper, no. 302. London: Oxford University Press.

Leifer, Michael (1999) 'The ASEAN Peace Process: A Category Mistake', The Pacific Review 12(1): 25-39.

Lenin, Vladimir (1948) Imperialism, the Highest Stage of Capitalism: A Popular Outline. London: Lawrence \& Wishart.

Lieber, Keir and Gerard Alexander (2005) 'Waiting for Balancing: Why the World is Not Pushing Back', International Security 30(1): 109-39.

Lipson, Charles (1993) 'International Cooperation in Economic and Security Affairs', in David Baldwin (ed.) Neorealism and Neoliberalism: The Contemporary Debate. New York: Columbia University Press.

Mansfield, Edward and Brian M. Pollins (eds) (2003) Economic Interdependence and International Conflict: New Perspectives on an Enduring Debate. Ann Arbor, MI: University of Michigan Press.

Mearsheimer, John (1995) 'The False Promise of International Institutions', International Security 19(3): 5-49.

Milner, Helen (1993) 'The Assumption of Anarchy in International Relations Theory: A Critique', in David Baldwin (ed.) Neorealism and Neoliberalism: The Contemporary Debate, pp. 143-69. New York: Columbia University Press.

Naisbitt, John (1995) Megatrends Asia: The Eight Asian Megatrends that are Changing the World. London: Nicholas Brealey.

Pape, Robert (2005) 'Soft Balancing against the United States', International Security 30(1): 7-45.

Paul, T.V. (2004) 'The Enduring Axioms of Balance of Power Theory', in T.V. Paul, James J. Wirtz and Michel Fortmann (eds) Balance of Power: Theory and Practice in the 21st Century, pp. 1-28. Stanford, CA: Stanford University Press.

Paul, T.V. (2005) 'Soft Balancing in the Age of US Primacy', International Security 30(1): 46-71.

Rohwer, Jim (1995) Asia Rising. New York: Simon \& Schuster.

Rose, Gideon (1998) 'Neoclassical Realism and Theories of Foreign Policy', World Politics 51(1): 144-72.

Rosecrance, Richard (1986) The Rise of the Trading State: Commerce and Conquest in the Modern World. New York: Basic Books.

Ruggie, John (1998) 'What Makes the World Hang Together?', International Organization 52(4): 855-85. 
Sachs, Jeffery (1997) 'The Wrong Medicine for Asia', New York Times 3 November: A2.

Severino, Rodolfo C. (1998) 'Weathering the Storm: ASEAN's Response to Crisis', Hong Kong. 11 June. See www.aseansec.org/3416.htm.

Simon, Sheldon (1995) 'Realism and Neoliberalism: International Relations Theory and Southeast Asian Security', The Pacific Review 8(1): 5-24.

Simon, Sheldon (1996) 'The Parallel Tracks of Asian Multilateralism', in Richard Ellings and Sheldon Simon (eds) Southeast Asian Security in the New Millennium, pp. 13-34. Armonk, NY: M.E. Sharpe.

Simon, Sheldon (2005) 'US-Southeast Asia Relations: Military Relations Restored with Indonesia, While US Passes on the First East Asia Summit', Comparative Connections (October-December 2005). Online version.

Soesastro, Hadi (2006) 'East Asia: Many Clubs, Little Progress', Far Eastern Economic Review 169(1): 50-3.

Stuart, Douglas and William Tow (1995) 'A US Strategy for the Asia-Pacific: Building a Multipolar Balance-of-Power System in Asia', Adelphi Paper, no. 299. London: The International Institute for Strategic Studies.

Stubbs, Richard (2002) 'ASEAN Plus Three: Emerging East Asian Regionalism', Asian Survey 42(3): 440-55.

Tasker, Rodney (1992) 'Facing Up to Security', Far Eastern Economic Review 6 August: $8-9$.

Tonnesson, Stein (2002) 'The Paracels: The “Other" South China Sea Dispute', Asian Perspective 26(4): 145-69.

Tow, William (2001) Asia-Pacific Strategic Relations: Seeking Convergent Security. Cambridge: Cambridge University Press.

Valencia, Mark (1995) 'China and the South China Sea Disputes', Adelphi Paper, no. 298. London: International Institute for Strategic Studies.

Vatikiotis, Micahael (1990) 'Yankee Please Stay: ASEAN Wants US Forces to Remain in Region', Far Eastern Economic Review 13 December: 30-2.

Vatikiotis, Michael (1991) 'Time to Rethink: ASEAN Leaders Mull Over Grouping's Future', Far Eastern Economic Review 21 March: 18-19.

Vatikiotis, Michael (1992) 'Time For Decision: Trade and Security Issues Will Dominate Summit', Far Eastern Economic Review 16 January: 23-4.

Vatikiotis, Michael (1993) 'Mixed Motives: Fear and Prospect of Profits Color ASEAN View of China', Far Eastern Economic Review 24 June: 13.

Vatikiotis, Michael (1998) 'Fund Under Fire', Far Eastern Economic Review 14 May: 60-3.

Vatikiotis, Michael, Anthony Rowley, Doug Tsuruoka and Shim Jar Hoon (1991) 'Building Blocs', Far Eastern Economic Review 31 January: 32-3.

Waltz, Kenneth (1979) Theory of International Politics. New York: McGraw-Hill.

Webber, Douglas (2001) 'Two Funerals and a Wedding: The Ups and Downs of Regionalism in East Asia and Asia-Pacific after the Asia Crisis', The Pacific Review 14(3): 339-72.

Wohlforth, William (1994) 'Realism and the End of the Cold War,' International Security 19(3): 91-129. 
Wong Kan Seng (1993) 'Welcome Remark H.E. Wong Kan Seng Minister of Foreign Affairs of The Republic of Singapore', Singapore, 26-28 July 1993. See http://www.aseansec.org/4884.htm.

World Bank (1993) The East Asian Miracle. Oxford: Oxford University Press.

Wu, Friedrich (1994) 'China Capitalizes on ASEAN', Far Eastern Economic Review 20 January: 17. 